\title{
De jure convergence, de facto divergence: A comparison of factual implementation of shareholder derivative suit enforcement in the United States and the United Kingdom
}

\author{
David Gibbs-Kneller* and David Gindis**
}

\begin{abstract}
Many legal systems have been converging toward a US shareholder-centric model of corporate law and governance. This includes de jure rules relating to derivative enforcement. Despite convergence of the UK system towards the US model, each system continues to diverge as regards levels of shareholder enforcement. This article suggests that this divergence can be explained by the way the courts implement the derivative procedure de facto. A comparative assessment of de facto implementation in the US and the UK reveals that while courts in both systems are reluctant to interfere with the business judgment of the board, the US courts are willing to analyse whether board decisions were substantively reached, contributing to the levels of enforcement based on the way costs are allocated. Conversely, ingrained traditions of the UK courts place a high evidentiary burden on the shareholder, which they are unlikely to meet. Since costs are allocated to the loser in the UK, the factual implementation continues to serve as a strong disincentive for private shareholder enforcement and good governance.
\end{abstract}

Keywords: derivative claims, enforcement, costs, civil procedure, judiciary, directors, shareholders, company law, corporate governance, convergence.

\section{Introduction}

Regarding private shareholder enforcement, a tension exists: the incentives of the actors 'may be excessive or insufficient, relative to the criterion of maximizing corporate value'. ${ }^{1} \mathrm{~A}$ derivative procedure may deter opportunistic management behaviour where less costly mechanisms have failed to do so. ${ }^{2}$ Yet, an accessible derivative procedure may create inadequate private incentives for shareholders to litigate where it is not in the company's, or society's, interests. Making the procedure accessible may inefficiently shift risk on to directors who will become risk-averse to the detriment of shareholders. ${ }^{3}$ Individual shareholders may lack the best incentive to maximise the wealth of the company and litigate if it serves their interests to do so regardless of the corporate purpose. Conversely, an inaccessible procedure that creates an incentive bias in favour of directors may undermine the deterrent function of

\footnotetext{
* Lecturer in Law, University of East Anglia, UEA Law School, UK. ORCID: 0000-0002-6596-8536

${ }^{* *}$ Senior Lecturer in Economics, University of Hertfordshire, Hertfordshire Business School, UK. ORCID:00000002-3869-7064

${ }^{1}$ R Kraakman et al., When Are Shareholder Suits in Shareholder Interests 82 Georgetown Law Journal 1733 , 1736 (1994).

${ }^{2}$ D Gibbs-Kneller and C Ogbonnaya, Empirical Analysis of the Statutory Derivative Claim: De Facto Application and the Sine Quibus Non, 19(2) Journal of Corporate Law Studies 303, 305 (2019); A Reisberg, Derivative Actions and Corporate Governance, 5.2.4, 5.4.2 (Oxford: OUP, 2007); R Thompson and R Thomas, The Public and Private Faces of Derivative Lawsuits 57(5) Vanderbilt Law Review 1747 (2004).

${ }^{3} \mathrm{D}$ Fischel and M Bradley, The Role of Liability Rules and the Derivative Suit in Corporate Law: A Theoretical and Empirical Analysis 71(2) Cornell Law Review 261, 265-6 (1986).
} 
derivative litigation. That is, where other mechanisms fail to control director self-interest, directors may act with impunity without the threat of enforcement to take away ill-gotten gains or compensate for a loss, thus harming corporate value. ${ }^{4}$ Failure to approximate the "efficient contract" between the parties means this tension may increase the agency costs incurred by the parties relative to the corporate purpose. ${ }^{5}$

In light of the corporate purpose, and as a way of resolving the tension, legal systems have been converging their legal rules toward a 'US-model' on derivative procedures as enacted (de jure). ${ }^{6}$ The aim of reforms are to improve corporate governance outcomes by reducing agency costs. $^{7}$ That is, deterring managerial opportunism while allowing directors to take decisions in good faith, free from shareholder interference. ${ }^{8}$ These reforms primarily involve restricting or enhancing shareholder power in relation to formal procedure, costs, and access to corporate information. ${ }^{9}$

Despite formal convergence increasing, systems continue to diverge in levels of derivative enforcement. This divergence has been explained as being a result of conditions precedent for enforcement, namely: standing requirements; allocation of litigation risk i.e. costs liability; access to information; and when it is possible to sue potential wrongdoers. ${ }^{10}$ Here we intend to add to this by identifying how factual implementation (de facto) of derivative procedures by the courts can contribute to a divergence of legal systems. We intend to show this by juxtaposing the de facto implementation in both the US and UK to consider why the UK has not observed a significant increase in derivative litigation despite converging toward a 'USmodel' de jure. ${ }^{11}$

Our explanation hinges on the fact that outcomes are not predicted solely on the basis of how legal rules are enacted. Courts do not make decisions in a vacuum. Legal decisions can affect the incentives of the actors, and not necessarily to the same degree. ${ }^{12}$ Regardless of how costs

\footnotetext{
${ }^{4}$ D Gibbs-Kneller and C Ogbonnaya (n 2).

${ }^{5}$ For discussion see, for example, D Gibbs-Kneller and C Ogbonnaya (n 2); M Siems, Private Enforcement of Directors' Duties: Derivative Actions as a Global Phenomenon in S Wrbka, S Van Uytsel and M Siems (eds), Collective Actions: Enhancing Access to Justice and Reconciling Multilayer Interests? (Cambridge: Cambridge University Press, 2012); J Armour et al., Private Enforcement of Corporate Law: An Empirical Comparison of the United Kingdom and the United States 6(4) Journal of Empirical Legal Studies 687, 688-9 (2009); A Reisberg, (n 2) passim.

${ }^{6}$ See, for example, M Siems, Convergence in Shareholder Law, 285-90 (CUP, 2008); M Siems, Derivative Actions as a Global Phenomenon (n 5) at 99.

${ }^{7}$ The view that corporate governance rules should be assessed in light of their capacity to reduce agency costs was pioneered by M Jensen and J Meckling, Theory Of The Firm: Managerial Behaviour, Agency Costs and Ownership Structure 3 Journal of Financial Economics 305 (1976).

${ }^{8}$ D Fischel and M Bradley, (n 3) at 270; J Coffee and D Schwartz, The Survival of the Derivative Suit: An Evaluation and a Proposal for Legislative Reform 81 Columbia Law Review 261, 287 (1981).

${ }^{9}$ For an overview of reforms to derivative claims see, M Siems, Derivative Actions as a Global Phenomenon (n $5)$.

${ }^{10}$ M Gelter, Why Do Shareholder Derivative Suits Remain Rare in Continental Europe 37 Brooklyn Journal of International Law 843, 856 (2012).

${ }^{11}$ For a comparison of enforcement levels in each system see, for example, J Armour et al. (n 5); D Gibbs-Kneller and C Ogbonnaya (n 2); S Ferris et al., Derivative Lawsuits as a Corporate Governance Mechanism: Empirical Evidence on Board Changes Surrounding Filings 42(1) The Journal of Financial and Quantitative Analysis 143, 150, 154 (2007); R Thompson and R Thomas (n 2).

${ }^{12}$ R Posner, Economic Analysis of Law, 32-3 (Wolters Kluwer $8^{\text {th }}$ ed, 2011); K Llewellyn, Some Realism About Realism - Responding to Dean Pound 44 Harvard Law Review 1222 (1931) - "Behind decisions stand judges... [who] have human backgrounds. Beyond rules... lie effects: beyond decisions stand people whom rules and decisions directly or indirectly touch".
} 
of litigation may be attributed, if the courts are not going to grant permission to continue a claim then shareholders are unlikely to utilise it. Shareholders will generally look for the "path of least resistance". ${ }^{13}$ It follows that changes in one institutional domain, in this case company law, without accompanying changes in other institutional domains, in this case court practices, are unlikely to yield the expected results. ${ }^{14}$

This article proceeds on the following basis. Section 2 identifies the structure of derivative procedures in both the UK and US as enacted de jure. This is to demonstrate how the UK has reformed its derivative procedure toward a US-model but also where variance remains. Section 3 then identifies how judges in each system implement derivative procedures de facto. Section 4 then concludes on the lessons learnt from this comparison, considering its effect on governance and agency costs in light of the corporate purpose.

\section{UK and US Derivative Claims: De Jure Perspective}

In this section we compare how de jure derivative procedures work in the US and the UK in order to show how reforms implemented in the UK Companies Act 2006 involved a clear move toward the US-model. Specifically, we focus on when a claim may be brought, how costs are allocated, and discovery and disclosure rules relating to corporate information.

\section{a. US Perspective I}

In the US, derivative procedures vary somewhat across different states. To avoid getting distracted by minor variations, we shall focus on the Model Business Corporation Act (MBCA), the framework state legislatures rely on to formulate their corporate law statutes. Given that a corporation's bylaws may require derivative litigation to be heard in a particular state, ${ }^{15}$ we shall also focus on case law across states.

Shareholders may bring an action in respect of a right vested in a company. ${ }^{16}$ Claims generally take the form of breaches of securities law or breaches of directors' duties. ${ }^{17}$ For standing under the MBCA, $\S 7.41$ a shareholder cannot commence proceedings unless they were a shareholder at the time the relevant conduct complained of took place or became shareholder through operation of law. The definition of 'shareholder' extends to beneficial owners. ${ }^{18}$ The shareholder must also "fairly and adequately" represent the interests of the corporation. ${ }^{19}$

\footnotetext{
${ }^{13} \mathrm{M}$ Gelter (n 10) at 870; see also A Reisberg (n 2) at 3.4.1.1

${ }^{14}$ More generally, outcomes in any system are determined by a myriad of variables, such as speed of judicial decision-making, social attitudes, and respect for the rule of law.

${ }^{15}$ A corporation may adopt any bylaws that are not inconsistent with law, MBCA, § 2.06(b); Delaware General Corporation Law (DGCL), s 109(b); Solak v Sarowitz, C.A. N0 12299 (Del. Ch. Dec 27, 2016).

${ }^{16}$ Federal Rules of Civil Procedure, Title V, Rule 23.1; MBCA, § 7.40; For State examples, Delaware General Corporation Law, § 365(a); California Civil Code, § 800(1); 2010 New York Code, Business Corporation Law, § 626, 717-20.

${ }_{17}$ J Armour et al. (n 5); S Ferris et al., (n 11) at 143, 150, 154; R Thompson and R Thomas, (n 2) at 1761.

${ }^{18}$ MBCA, $\S 7.40$.

${ }^{19}$ MBCA, § 7.41(2); cf. DGCL, § 367.
} 
The MBCA also embodies a "demand requirement". ${ }^{20}$ It is "a general rule [that a] stockholder cannot be permitted ... to invade the discretionary field committed to the judgment of the directors and sue in the corporation's behalf when the managing body refuses'. ${ }^{21}$ Under Federal Rules of Civil Procedure, Rule 23.1, pleading to commence derivative litigation must show that the efforts the shareholder made to obtain the desired action from the company or the reasons for not doing so: ${ }^{22}$

The demand requirement serves a salutary purpose. First, by requiring exhaustion of intracorporate remedies, the demand requirement invokes a species of alternative dispute resolution procedure which might avoid litigation altogether. Second, if litigation is beneficial, the corporation can control the proceedings. Third, if demand is excused or wrongfully refused, the stockholder will normally control the proceedings. $^{23}$

This pre-suit demand is 'designed to create a balanced environment which will... deter costly, baseless suits by creating a screening mechanism to eliminate claims where there is only a suspicion expressed solely in conclusory terms'. ${ }^{24}$ However, pre-suit demand may be excused or shown as wrongfully refused that will allow shareholders to continue with proceedings for the company. ${ }^{25}$

Even if the shareholder can show demand was wrongfully refused or is otherwise excused, the company may still turn to a special litigation committee. ${ }^{26}$ "Qualified directors" 27 may dismiss a claim if it is determined in good faith after a reasonable enquiry that derivative proceedings are not in the best interests of the company. It is the burden of the plaintiff to show this has not been met if the majority of the board consists of qualified directors. ${ }^{28}$ A special litigation committee's decision is still subject to judicial review. A reviewing court will place the burden on the company to demonstrate it was independent and acted in good faith. If so, the court will then apply its own business judgment to determine whether permission should be granted. ${ }^{29}$ In Re Southern Peru Copper Corporation Shareholder Derivative Litigation, it was said, 'the test, therefore, seems to contemplate a look back at the substance, and efficacy, of the special committee's negotiations, rather than just a look at the composition and mandate of the special committee'. ${ }^{30}$

Under 'American rule' each side pays their own fees, subject to fee-shifting provisions. ${ }^{31}$ Principally, the plaintiff's fees may be shifted to the company if the plaintiff achieves a

\footnotetext{
${ }^{20}$ MBCA, $\S 7.42$; see also Federal Rules of Civil Procedure, Title V, Rule 23.1(b)(3); New York Code, Business Corporation Law, § 626(c).

${ }^{21}$ Mckee v Rogers, 156 A. 191, 193 (Del. Ch. 1931).

${ }^{22}$ Federal Rules of Civil Procedure, Title V, Rule 23.1; Kamen v Kemper Financial Services., 111 S.Ct. 1711, 1716-7 (1991) - Federal courts will apply state demand laws unless they are in conflict with federal laws.

${ }^{23}$ Grimes v Donald, Del. Supr., 673 A.2d 1207, 1216 (1996).

${ }^{24}$ Brehm v Eisner 746 A.2d 244, 255 (Del. 2000).

${ }^{25}$ Brehm v Eisner 746 A.2d 244, 253 (Del. 2000).

${ }^{26} \mathrm{MBCA}, \S 7.44$.

${ }^{27} \mathrm{MBCA}, \S 1.43$.

${ }^{28} \mathrm{MBCA}, \S 7.44(\mathrm{e})$.

${ }^{29}$ Zapata Corporation v Maldonado, 430 A.2d 779, 788-9 (1981).

${ }^{30}$ Re Southern Peru Copper Corporation Shareholder Derivative Litigation, 52 A.3d 761, 788 (Del. Ch. 2011).

${ }^{31}$ MBCA, § 7.46; see also, Federal Rules of Civil Procedure, 11(b)(2); Del Supreme Court Civil Rules, Rule 11(b)(2).
} 
"substantial benefit" for the company. ${ }^{32}$ The award does not have to be monetary but extends to "therapeutic remedies". ${ }^{33}$ The shareholder is also able to seek out contingency fee arrangements. Thereby, American rule on costs means shareholders run very little risk in commencing derivative litigation unless there is fee shifting for commencing derivative proceedings unreasonably or for an improper purpose. The way the costs are distributed resulted in measures being introduced against 'strike suits', such as requiring court assent to discontinue or settle proceedings. ${ }^{34}$ This restricts shareholders from using derivative litigation to try and extort a settlement from the company.

Rules relating to information disclosure, or 'discovery' rules, are a federal matter. ${ }^{35}$ The power to discover information is broad if the shareholder satisfies the pleading requirements, extending to any matter that is not privileged. However, the rules relating to disclosure at the pleading stage do not apply. The shareholder will not have the benefit of these extensive discovery rules to demonstrate demand should be excused or was wrongfully refused. ${ }^{36}$ The shareholder will have to rely on more limited tools of discovery to successfully plead for relief. ${ }^{37}$

Payment of expenses and fees for disclosure follow a similar path to that of costs generally. ${ }^{38}$ The risk of fee shifting on to shareholders would appear to be greater in pre-action disclosures given the wide discovery power once an action commences.

\section{b. UK Perspective I}

The current legal regime in the United Kingdom on derivative claims is found in the Companies Act 2006, Pt 11. The evidence that shows the UK has converged toward a 'US-model' of derivative claims in the 2006 Act can be seen through the transition to it from its predecessor, the equitable procedure. ${ }^{39}$ Under the equitable procedure permission was only available to minority or equal shareholders who could show sufficient merit to a claim in a very narrow set of circumstances that were opaquely generalised as "fraud on the minority" where "wrongdoers" were in control of the company. ${ }^{40}$ Furthermore, the equitable procedure required consideration of whether the shareholder was the "proper person" to enforce the company's rights. ${ }^{41}$ The "proper person" test prevented relief if the defendant could establish a principle why the claimant was not the proper person to bring the claim. If the company had not been

\footnotetext{
${ }^{32}$ MBCA, § 7.46(1); Shelnsky v Dorsey 574 F.2d 131, 149 (3d Circ 1978); Chrysler Corp v Dann 43 Del. Ch. 252, 223 A.2d 384 (Del. 1966).

${ }^{33}$ Mills v Electric Auto-Lite Co, 396 US 375 (1970); Chrysler Corp v Dann 43 Del. Ch. 252, 223 A.2d 384 (Del. 1966); Rosenthal b Burry Discuit Corp., 42 Del. Ch. 279, 209 A.2d 459 (1949).

${ }^{34}$ MBCA, § 7.45.

${ }^{35}$ Federal Rules of Civil Procedure, Title V, Rules 26-37.

${ }^{36}$ Levine v Smith, Del. Supr., 591 A.2d 194, 208-210 (1991).

${ }^{37}$ See, for example, Rales v Blasband, Del.Supr., 634 A.2d 927, 935 n. 10 (1993); DGCL, s 220; The Pennsylvania Rules of Civil Procedure, Ch 4003.8.

${ }^{38}$ Federal Rules of Civil Procedure, Title V, Rule 37(5).

39 That is claims heard in exception to the rule in Foss $v$ Harbottle (1843) Hare 461 and in reference to the Civil Procedure Rules, rule 19.9.

${ }^{40}$ Estmanco (Kilner House) Ltd v Greater London Council [1982] 1 W.L.R. 2, 10-2.

${ }^{41}$ Airey v Cordell [2006] EWHC 2728 (Ch); [2007] BCC 785 at [72]; citing J Gower, Principles of Modern Company Law, 652 (4th edn, Sweet \& Maxwell 1997); Barrett v Duckett [1995] 1 BCLC 243, 367; see also, Nurcombe v Nurcombe [1985] 1 WLR 370, 376.
} 
improperly prevented from enforcing its rights; ${ }^{42}$ improper motives; $;{ }^{43}$ and the availability of adequate alternative remedies ${ }^{44}$ were all established principles to prevent permission being granted. ${ }^{45}$ The directors need only establish a single principle from many as to why the shareholder should not enforce the company's rights.

A myriad of other reasons, such as costs and information asymmetry, contributed to the limited use of private enforcement. These reasons created a strong incentive bias in favour of directors. Such was the limited use of the equitable procedure it did not even warrant inclusion in a comparative study on derivative actions, ${ }^{46}$ while another empirical study revealed there were effectively zero derivative claims filed against directors of public companies in the UK. ${ }^{47}$ Curiously, recent comparative studies on derivative procedures in European states have almost entirely ignored the UK system. ${ }^{48}$

Now the statutory procedure more closely resembles that of the US-model. At what is often referred to as the 'first stage' of the statutory derivative claim, the courts will assess whether a claimant satisfies formal requirements on ex parte application. That application must disclose a prima facie case. ${ }^{49}$ There is no indication in the Act that this first stage will involve a meritsbased assessment of the claim. Instead, the application must merely be contextualised on the correct grounds for a cause of action with supporting evidence. ${ }^{50}$ Those grounds permit any member ${ }^{51}$ of the company to commence a claim under the statutory procedure where there is a cause of action vested in the company. ${ }^{52}$ They do not have to have been a shareholder at the time the cause of action arose $\mathrm{s}^{53}$ nor are there minimum ownership requirements to commence a claim. The claim must be brought against a director ${ }^{54}$ where there is a right of action vested in the company in relation to a breach of duty, trust, negligence or default. ${ }^{55}$ This includes claims against third parties provided that claim does not arise independently of the director's conduct. ${ }^{56}$

\footnotetext{
${ }^{42}$ Barrett v Duckett [1995] 1 BCLC 243, 368-9; Fargro Ltd v Godfroy [1986] 1 WLR 1134, 2 BCC 99, 167.

${ }^{43}$ Barrett v Duckett [1995] 1 BCLC 243, 367; Smith v Croft (No 1) [1986] 1 W.L.R. 580, 590.

${ }^{44}$ Barrett v Duckett [1995] 1 BCLC 243, 367; cited by Konamaneni v Rolls Royce [2002] 1 WLR 1269, 1279.

${ }^{45}$ Other reasons included: Airey v Cordell [2006] EWHC 2728 (Ch); [2007] BCC 785 at [53]; Burland v Earle [1902] AC 83, 93 - whether the conduct is capable of being ratified; Airey v Cordell [2006] EWHC 2728 (Ch); [2007] BCC 785 at [53]; Smith v Croft (No 2) [1988] Ch 114; Smith v Croft (No 1) [1986] 1 W.L.R. 580, 590; Wallersteiner v Moir (No 2) [1975] QB 373, 404 -independent views; Harley Street Capital Ltd v Tchigirinsky (No.2) [2005] EWHC 1897 (Ch) at [14]; Nurcombe v Nurcombe [1985] 1 WLR 370, 377; Towers $v$ African Tug Co [1904] 1 Ch 558, 562 - if the plaintiff had wasted time or delayed in brining proceedings; Airey v Cordell [2006] EWHC 2728 (Ch); [2007] BCC 785 at [72]; Towers v African Tug Co [1904] 1 Ch 558, 568 - if the shareholder participated in the wrong complained of; Nurcombe v Nurcombe [1985] 1 WLR 370, 378 - whether there were any equitable defences to the claim.

${ }^{46}$ M Siems, Derivative Actions as a Global Phenomenon (n 5).

${ }^{47} \mathrm{~J}$ Armour et al. (n 5).

${ }^{48}$ M Gelter (n 10); K Grechenig \& M Sekyra, No Derivative Shareholder Suits in Europe: A Model of Percentage Limits and Collusion 31 International Review of Law \& Economics 16 (2011).

${ }^{49}$ Companies Act 2006, s. 261(2).

${ }^{50}$ See, for example, Civil Procedure Rules, PT 19.5; Re Seven Holdings Ltd [2011] EWHC 1893 (Ch) at [35], [62].

${ }^{51}$ Companies Act 2006, ss 112, 260(5)(c).

${ }^{52}$ Companies Act 2006, s. 260(1).

${ }^{53}$ Companies Act 2006, s. 260(4).

${ }^{54}$ Companies Act 2006, s. 260(5).

${ }_{55}^{55}$ Companies Act 2006, s. 260(3).

${ }^{56}$ Iesini v Westrip Holdings Ltd [2009] EWHC 2526 (Ch) at [75]; [79]; SDI Retail Services Ltd v King [2017] EWHC 737 at [49].
} 
The similarities to the US system continue at the 'second stage' ${ }^{57}$ Here the statutory procedure hands substantive control of permission to continue a derivative claim to the court. Similar to the demand requirement, discretion is restricted where there has been effective ratification or authorisation $^{58}$ but also when a director acting in accordance with section 172 would not continue the claim. ${ }^{59}$ If none of these are established, discretion is granted to the court to 'determine what the company actually wants' by taking 'in to account all the factors set out'. ${ }^{60}$ This resembles the 'fairly and adequately' and demand requirements of the US system. That is, the courts are no longer required to dismiss a claim if the claim does not demonstrate sufficient legal merit or defendants establish a principle is under the proper person test to dismiss the claim. Also, demand in the US must be made unless excused and a refusal can only be challenged if it is wrongful. Under the statutory procedure, the courts are guided to consider the views of the company and the shareholders, but they are not necessarily conclusive. ${ }^{61}$ Indeed the discretion, as enacted, appears to go further than the US system. Shareholders in the US must produce evidence that creates reasonable doubt that demand was wrongfully refused or should be excused. The UK, however, is simply guided to consider all the circumstances.

With regard to information disclosure and costs, the rules have not changed. Pre-suit Information rules offer limited access to shareholders, similar to the US. Shareholders do not automatically have a right to inspect company documents. ${ }^{62}$ Company investigations via a "competent inspector" are possible but the formal requirements, such as quoracy and security, limit the utility of the mechanism. ${ }^{63}$ The statutory procedure does not make specific provisions for shareholder information disclosure. ${ }^{64}$ Pre-action disclosures are possible but the utility of this is also very limited. ${ }^{65}$ Courts are slow to permit disclosures, shareholders lack the basic knowledge to identify the relevant information required, the potential liability for costs for preaction disclosures, and since most claims involve fraud any investigation is practically difficult. ${ }^{66}$ However, once proceedings do commence disclosure of documents by the company is required. ${ }^{67}$ Therefore, the UK procedure permits greater access to information to shareholders when determining whether they should control the proceedings than the US system, but has similar rules regarding pre-suit disclosures.

Fundamental variance remains between each system with regard to costs. Under 'English rule' the loser pays the opposing side's costs. ${ }^{68}$ While directors might have reputational and resource

\footnotetext{
${ }^{57}$ Companies Act 2006, subss 263(2)-(3).

${ }^{58}$ Companies Act 2006, subss 263(2)(b), (c).

${ }^{59}$ Companies Act 2006, s. 263(2)(a).

${ }^{60}$ Hansard HL, Vol 679, Official Report, 27/2/2006 Col GC26.

${ }^{61}$ Companies Act 2006, ss 263(3)(c), (e), (4).

${ }^{62}$ The Companies (Model Articles) Regulations 2008 No 3229, Sch I, Art. 50 (Ltd); Sch III, Art. 83 (plc) - Except as provided by law or authorised by the directors or an ordinary resolution of the company, no person is entitled to inspect any of the company's accounting or other records or documents merely by virtue of being a member/shareholder.

63 See, Companies Act 1985, Pt XIV.

${ }^{64}$ Companies Act 2006, s. 261(4) - but the court may give directions as it sees fit.

${ }^{65}$ Civil Procedure Rules 31.16.

${ }^{66} \mathrm{C}$ Paul, Derivative Actions under English and German Corporate Law - Shareholder Participation between the Tension Filled Areas of Corporate Governance and Malicious Shareholder Interference, European Company and Financial Law Review 81 (2010); see also, Axa Equity \& Law Life Assurance Society plc v National Westminster Bank [1998] C.L.C. 1177.

${ }^{67}$ Civil Procedure Rules, rule 31.6.

${ }^{68}$ Civil Procedure Rules, 44.3(2)(a); see also Wallis v Duke of Portland 3 Ves. Jun. 494 per Lord Loughborough regarding justifications for such a rule; cf. Martell v Consett Iron Co Ltd [1955] Ch 363, 399-400; J Bentham, A
} 
concerns to consider ${ }^{69}$ the cost of litigation may otherwise be borne by the company. On the other side the shareholder has considerable personal risk in financing the litigation. They have the burden of proof in pre-action disclosures and on satisfying the court that the claim should continue.$^{70}$ While there is no direct change in the Act, ${ }^{71}$ rules on contingency fees have been relaxed $^{72}$ and indemnity orders are available. ${ }^{73}$ The problem here is that there are no clear grounds on when an indemnity order will be granted, and they are only granted after the claim has been heard. Seldom are they granted and, if they are, the amount may be capped and/or not cover the full amount. ${ }^{74}$ However, the concern about costs may be alleviated by the increase in third party litigation funds being available, reducing the risk to shareholders. ${ }^{75}$

Under the equitable procedure, all three elements discussed contributed to a significant incentive bias in favour of directors in derivative enforcement. ${ }^{76}$ These limited the utility of the procedure for shareholders. While only the formal procedure has been reformed, the effect of costs liability and information asymmetry may be indirectly marginalised dependent on how willing the courts are to overlook or challenge the incentives bias in favour of directors in derivative litigation. If courts are willing to overlook matters such as information asymmetries and ignore potentially "weak or disingenuous" 77 reasons offered by directors on why litigation should not continue or the shareholder is not the proper person, such willingness will shift risk away from the shareholders onto directors. This should make the statutory procedure of greater value to shareholders and more frequently accessible for them to utilise. ${ }^{78}$ Simultaneously, not only will the probability of costs liability shift towards the company, directors will also risk personal reputational harm and have valuable resources deflected away from corporate objectives. Therefore, they will either have to expend more resources in challenging a claim, such as forming potentially expensive independent litigation committees, or will be

Defence of Usury, Letter XII, Maintenance and Champerty in Bowring (ed), The Works of Jeremy Bentham, Volume 3, Part 1, at 19 (William Tait: Edinburgh, 1843).

${ }^{69}$ A Reisberg, (n 2) at ch 2.2; S Kalss, Shareholder Suits: Common Problems, Different Solutions and First Steps towards a Possible Harmonisation by Means of A European Model Code, European Company and Financial Law Review 324, 332 (2009).

${ }^{70}$ Barrett v Duckett [1995] 1 BCLC 243, 249; Airey v Cordell [2006] EWHC 2728 (Ch); [2007] BCC 785 at [59], [73].

${ }^{71}$ For a discussion on reform to litigation funding generally, see, for example, $\mathrm{M}$ Zander, Will the Revolution in the Funding of Civil Litigation in England Eventually Lead to Contingency Fees? 52 DePaul Law Review 259 (2002).

${ }^{72}$ Access to Justice Act 1999, ss 27-8; Conditional Fee Agreements (Revocation) Regulations 2005, SI 2005/2305; see also, Legal Aid, Sentencing and Punishment of Offenders Act 2012, s 45; and The Damage-Based Agreements Regulations 2013, SI 2013/609.

${ }^{73}$ Civil Procedure Rules, pt 19.2(2).

${ }^{74}$ See, for example, B Cheffins and B Black, Outside Director Liability Across Countries 84(6) Texas Law Review 1385, 1406 (2006); Stainer v Lee [2010] EWHC 1539 (Ch); [2011] BCC 134 at [56]; Smith v Croft [1986] 1 WLR 580, 597.

${ }^{75}$ See, Arkin v Borchard Lines Ltd [2005] EWCA Civ 655; Financial Times, Litigation lawyers: heavy mob's hot money, Business (June 11 ${ }^{\text {th }}$, 2018) p 12; cf. Factortame v Secretary of State for Transport (No 8) [2003] QB 381, 400; Giles v Thompson [1994] 1 AC 142; and British Cash and Parcel Conveyors v. Lamson Store Service Company [1908] 1 KB 1006, 1014 - noting that any such arrangements should not be made simply to meddle in disputes the third party had no interest in.

${ }^{76}$ For examples of bias, see A Reisberg, (n 2) at 3.2.3; L Bebchuk and J Fried, Pay Without Performance: The Unfulfilled Promise of Executive Compensation, 31-4 (Harvard University Press, 2006); J Coffee and D Schwartz (n 8) at 283; M Klein, Conduct of Directors When Litigation is Commenced Against Management 31(2) Business Lawyer 1355 (1976), 1359; R Buxbaum, Conflicts of Interests Statutes and the Need for a Demand on Directors in Derivative Statutes 68(6) California Law Review 1122 (1980).

77 J Coffee and D Schwartz (n 8) at 287; see also, A Reisberg, (n 2) at 3.4.1.1.

${ }^{78} \mathrm{M}$ Gelter (n 10) at 863. 
incentivised to settle any claims brought if the cost of doing so is less than the potential costs in litigation. However, if courts remain unwilling to allow claims, even if conditional fee arrangements and litigation funds from third parties have become more frequently available, access to information and costs are likely to remain a significant deterrent to litigation. ${ }^{79}$

\section{UK and US Derivative Claims: De Facto Perspective}

As we have discussed, the statutory procedure in the UK now resembles the US model in many key respects, although some differences remain. We set aside de jure differences and focus on what happens de facto when courts need to examine a derivative claim. Factual implementation can contribute to a divergence of legal systems.

\section{a. US Perspective II}

Procedural requirements as enacted deter enforcement, ${ }^{80}$ but what factual implementation reveals is that the court invariably refers to the business judgment of the board in relation to demand requirements and special litigation committees, which creates practical difficulties for shareholders to enforce rights derivatively. However, what matters is the willingness of the court to check that judgment was reached after a thorough analysis by the board or its committee. In light of the judicial willingness to review decisions, the way costs will be allocated if litigation continues incentivises shareholders and their attorney to litigate and for risk averse directors to settle at a lower rate. De facto implementation contributes to higher levels of enforcement in the US.

There are several aspects of US derivative litigation that require some substantive review of the court. The first is whether the shareholder "fairly and adequately" represents the interests of the company. The approach taken by the courts is factual of all the relevant circumstances. For example, Davis v Comed Inc listed relevant factors to be considered under Rule 23.1: (1) any economic antagonism; (2) the remedy the plaintiff seeks; (3) any indication the shareholder was not the driving force behind the litigation; (4) other litigation pending between the parties; (5) relative magnitude of plaintiff's personal interests as compared to his interest in the derivative action; and (6) the degree of support received from other shareholders. ${ }^{81}$

The courts do not appear to have a hierarchy or have any pre-determined weight assigned to any particular fact. This places shareholders in a good position initially to bring derivative proceedings. Derivative procedures are naturally adversarial and tainted with acrimony where the parties have fallen out. There will be suggestions that the shareholder is motivated

\footnotetext{
${ }^{79}$ Arkin v Borchard Lines Ltd [2005] 1 WLR 3055, 3069-70 - particularly as the third party litigation funder may be liable for the opposing party's costs.

${ }^{80}$ For a discussion on US procedural disincentives to derivative litigation see, for example, J Matheson, Restoring the Promise of the Shareholder Derivative Suit 50(2) Georgia Law Review 327 (2016); G Geis, Shareholder Derivative Litigation and the Preclusion Problem 100(2) Virginia Law Review 261 (2014); R Thompson and R Thomas (n 2) at 1773-4; G Dent, The Power of Directors to Terminate Shareholder Litigation: The Death of the Derivative Suit? 75(1) Northwestern University Law Review 96 (1980); G Hornstein, The Death Knell of Stockholders' Derivative Suits in New York 32 California Law Review 123 (1944).

${ }^{81}$ Davis $v$ Comed Inc, 619 F.2d 588 (6 $6^{\text {th }}$ Cir 1980).
} 
otherwise than for the company's interests. Yet, unlike the old UK equitable procedure, the shareholder may still continue in spite of reasons existing for dismissal if, on the whole, they are determined to fairly and adequately represent the interests of the company. Therefore, in one decision, while the shareholder's motivations were tainted by an ulterior motive to protect their interest as a creditor, the court concluded the shareholder did fairly and adequately represent the interests of the company. ${ }^{82}$ Conversely, a claim brought by a shareholder seeking to recover a percentage of the purchase price from the previous management did not fairly and adequately represent the company's interests. Permission would result in unjust enrichment. ${ }^{83}$ In another claim a shareholder fraught with conflicts of interest was not said to fairly and adequately represent the interests of the company. ${ }^{84}$ The courts approach is then not a negative one looking for reasons to dismiss like the proper person test, but one that assesses the adequacy of the shareholder to fairly enforce the company's rights by balancing the relevant circumstances.

Demand must also be made on the company. Unless it is excused or wrongfully refused, the shareholder will not be able to continue. ${ }^{85}$ To determine if demand should be excused or was wrongfully refused, 'the Court of Chancery in the proper exercise of its discretion must decide whether... a reasonable doubt is created that: (1) the directors are disinterested and independent [or] (2) the challenged transaction was otherwise the product of a valid exercise of business judgment'. ${ }^{86}$

This presents a particular problem for shareholders. For the demand requirement to be excused or shown as wrongfully refused the shareholder must 'articulate particularized facts showing that there is a reasonable doubt either that (a) a majority of the board is independent for purposes of responding to the demand, or (b) the underlying transaction is protected by the business judgment rule'. ${ }^{87}$ This is a particularly "heavy burden" 88 as the presumption is in favour of directors that the decision by the board was taken in the best interests of the company. ${ }^{89}$ Independence is generally assumed absent of some conflicting financial arrangement ${ }^{90}$ and the transaction will not be impugned if the board had proper processes in place to review the conduct. ${ }^{91}$ Given the rise in number of independent directors, requiring demand to be excused on the basis of futility or that it was wrongful should limit derivative litigation. ${ }^{92}$

\footnotetext{
${ }^{82}$ Meredith v Camp Hill Estates Inc., 77 A.D.2d 649, 430 NYS.2d 383 (1980).

${ }^{83}$ Bangor Punta Operations Inc v Bangor \& Aroostook Railroad Co, 417 US 703 (1974).

${ }^{84}$ Steinberg v Steinberg, 106 Misc 2d 720, 434 NYS.2d 877 (Sup. Ct. 1980).

${ }^{85}$ Lewis v Graves, 701 F.2d 245, 247-8 (2d Cir. 1983); For the difference between demand excused/refused and wrongful refusal see, for example, Grimes v Donald, Del. Supr., 673 A.2d 1207, 1217-8 (1996); Scattered Corp. $v$ Chicago Stock Exch., Del.Supr., 701 A.2d 70 (1997).

${ }^{86}$ Brehm v Eisner 746 A.2d 244, 253 (Del. 2000).

${ }^{87}$ Brehm v Eisner 746 A.2d 244, 255 (Del. 2000); see also, Kamen v Kemper Financial Services., 939 F.2d 458, 460-61 (7th Cir. 1991); Levine v Smith, Del. Supr., 591 A.2d 194, 207 (1991).

${ }^{88}$ Levine v Smith, Del. Supr., 591 A.2d 194, 208 (1991).

${ }^{89}$ Spiegel v Buntrock, Del. Supr., 571 A.2d 767, 773 (1990).

${ }^{90}$ Beam v Martha Stewart, 845 A.2d 1040, 1050 (2004) - independence is not impugned solely on the basis of friendships or outside business relationships; see also R Thompson and R Thomas (n 2) at 1782.

${ }^{91}$ See, for example, Re Walt Disney Co. Derivative Litigation, 825 A.2d 275 (Del. Ch. 2003); Aronson v Lewis, 473 A.2d 805, 810 (Del. 1984).

${ }^{92}$ See R Thompson and R Thomas (n 2) at 1748.
} 
The problem of discharging this burden is exemplified by the fact requests for pre-trial discovery under Federal Rules 26-37 is not permitted in demand-refused cases. ${ }^{93}$ Nor is it available in demand-excused cases, except where a special litigation committee has been formed. ${ }^{94}$ Shareholders must first satisfy the pleading requirements set out in Rule 23.1, or the respective state requirements, for bringing a derivative action. ${ }^{95}$ In Levine $v$ Smith, the board had refused demand, and the shareholder failed to challenge that decision. The court held the decision was a matter of business judgment and the shareholder had failed in their burden of demonstrating sufficient doubt that the decisions was reached without due care. The request for pre-trial discovery by written interrogatories and requests for production of documents was not permitted. Because demand excused or wrongfully refused is reviewed at the pleading stage, shareholders do not have the benefit of discovery. ${ }^{96}$ In Brehm v Eisner, discovery under the Federal Rules of Civil Procedure was also refused. Where the shareholders already had the "tools at hand" to identify particularised facts to satisfy the demand requirements in Rule 23.1, a lack of pre-trial disclosure was no answer to the failure to do so. ${ }^{97}$

However, those tools may also lack sufficient utility in giving shareholders access to information needed to satisfy their evidentiary burden. They could obtain disclosure of books and records under DGCL, s 220 but only if they can show there was a "legitimate chance" their claim of mismanagement or wrongdoing was credible. ${ }^{98}$ In another, the claimant was denied access to inspect the company's books. The claimant did not meet the evidentiary burden to demonstrate a "proper purpose" to inspect. Seinfeld failed to "present some evidence to suggest a credible basis from which a court can infer that mismanagement, waste or wrongdoing may have occurred'. The court continued that the "credible basis" standard is a judicial balance between the rights of shareholders to obtain information and directors to run the company free from unnecessary interference. ${ }^{99}$ A mere statement of purpose to investigate mismanagement will be insufficient as a mere "indiscriminate fishing expedition". 100

Although shareholders have a wide discovery powers if demand is excused or wrongfully refused, the limits on pre-suit disclosure at the demand stage place a significant obstacle in front of shareholders to demonstrate reasonable doubt. As the counsel acknowledged in Levine, refusal to disclose documents can tilt "the scales [in favor of the board]" permitting "a corporate board to simply refuse a shareholder's demand for action with impunity." ${ }^{101}$ The board's refusal

\footnotetext{
${ }^{93}$ Levine v Smith, Del. Supr., 591 A.2d 194, 210 (1991).

${ }^{94}$ Aronson v Lewis, 473 A.2d 805 (Del 1984); Lewis v Hilton, 648 F. Supp. 725, 727-8 (N.D.Ill.1986); cf. Zapata Corporation v Maldonado, 430 A.2d 779 (1981).

${ }^{95}$ Levine v Smith, Del. Supr., 591 A.2d 194, 208-210 (1991).

${ }^{96}$ For an overview of the relevant case law see, Note 'Discovery in Federal Demand-Refused Derivative Litigation 105 Harvard Law Review 1025, 1027 (1992).

${ }^{97}$ Brehm v Eisner, 746 A.2d 244, 262 n 57, 266 (Del. 2000); see also Grimes v Donald, Del. Supr., 673 A.2d 1207, 1216 (1996); Rales v Blasband, Del.Supr., 634 A.2d 927, 935 n. 10 (1993).

98 Seinfeld v Verizon Communications Inc, 909 A.2d 117, 120 (2006); Security First Corp. v U.S. Die Casting \& Dev. Corp., Del.Supr., 687 A.2d 563, 567-569 (1997); the requirement is the same in other states such as Kansas, Arctic Fin. Corp. v. OTR Express, Inc., 272 Kan. 1326, 38 P.3d 701, 703-04 (2002); and Vermont, Towle v. Robinson Springs Corp., 168 Vt. 226, 719 A.2d 880, 882 (1998); see also, Saito v McKesson HBOC Inc, 806 A.2d 113 (2002) - requiring the claim to be reasonably related to their interests as shareholder.

${ }^{99}$ Seinfeld v Verizon Communications Inc, 909 A.2d 117, 118, 122 (2006).

100 Security First Corp. v U.S. Die Casting \& Dev. Co., 687 A.2d 563, 571 (Del.1997); see also Helmsman Management Services Inc. v A \& S Consultants, Inc., 525 A.2d 160, 166 (Del.Ch.1987).

${ }^{101}$ Levine v Smith, Del. Supr., 591 A.2d 194, 209 (1991); see also, Seinfeld v Verizon Communications Inc, 909 A.2d 117, 120-1 (2006).
} 
may be no more than a brief statement acknowledging that the board has considered the demand and refused it. ${ }^{102}$ By shifting the burden on to the shareholder to demonstrate a wrongful refusal without disclosure:

It is difficult for shareholders who have no information about a corporation's investigatory procedures to create a reasonable doubt that a corporation adequately investigated a demand. Such decisions create a virtually insurmountable obstacle for shareholders who have no knowledge of the internal corporate decisionmaking process and will effectively bar many derivative suits regardless of their merit. ${ }^{103}$

This issue of discovery is overcome if the board defers the decision to a special litigation committee:

The act of establishing a special litigation committee constitutes an implicit concession by a board that its members are interested in the transaction and that its decisions are not entitled to the protection of the business judgment rule. See Abbey v. Computer \& Communications Technology Corp., Del.Ch., 457 A.2d 368, 374 (1983). However, as we stated in Spiegel, a board of directors concedes demand futility when it is both interested and establishes a special litigation committee to resolve the derivative plaintiff's suit. 571 A.2d at 777 (quoting Abbey, 457 A.2d at 373); see also Aronson, 473 A. $2 \mathrm{~d}$ at 814 . Therefore, demand is excused and discovery is allowed. ${ }^{104}$

Rule 23.1 does not strip the board of its decision-making powers and they may legitimately delegate the litigation decision to an independent litigation committee. ${ }^{105}$ The decision of a special litigation committee is subject to judicial review. The decision of the committee is not one of mere "business judgment", like that of demand refusal, and 'the final substantive judgment whether a particular lawsuit should be maintained requires a balance of many factors ethical, commercial, promotional, public relations, employee relations, fiscal as well as legal'. 106

The problem for shareholders of overcoming independent business judgements persists, however. Where an independent committee reaches a decision in good faith, the court is willing to review business decisions and apply its own judgment on whether litigation should commence. However, the data shows litigation committees almost invariably resolve to dismiss the litigation and courts are unwilling to second-guess validly reached decisions. ${ }^{107}$ Structural bias in the corporate structure means independent directors are likely to rally around their own kind. ${ }^{108}$ Formal independence is used in a matter of fact to deny possible conflicts. The subtler

\footnotetext{
102 See, for example, Grimes v Donald, Del. Supr., 673 A.2d 1207, 1212 (1996).

103 Note (n 96) at 1028-9.

${ }^{104}$ Levine v Smith, Del. Supr., 591 A.2d 194, 209 (1991); see also Re Par Pharmaceutical, Inc. Derivative Litigation, 750 F. Supp. 641, 647 (S.D.N.Y. 1990) - "if the special litigation committee recommends termination and a motion for summary judgment follows, the committee must fully disclose its report and the underlying data".

105 Zapata Corporation v Maldonado, 430 A.2d 779, 786 (1981).

${ }^{106}$ Zapata Corporation v Maldonado, 430 A.2d 779, 788 (1981).

107 J Cox, Searching For the Corporation's Voice in Derivative Suit Litigation: A Critique of Zapata and the ALI Project 6 Duke Law Journal 959, 963 (1982) - citing only one instance of a committee siding with the shareholder, Abramowitz v Joy, North, No. B-77-385 (D. Conn. July 16, 1980).

${ }^{108}$ L Bebchuk and J Fried (n 76) at 31-4; M Klein (n 76) at 1359; R Buxbaum, (n 76).
} 
forms of steering the company in a particular direction or protecting directors as peers fall between the cracks. ${ }^{109}$

The judicial decisions also show the unwillingness of courts to form their own business judgment. In one case, the court's review concluded that the committee's decision had been made in good faith in light of all the circumstances. It was their sound business judgment that litigation was not in the company's interests. ${ }^{110}$ It is only where the committee fails to adequately address the litigation question will derivative litigation continue, but even here the court does not substitute its own business decision. ${ }^{111}$

Therefore, even with the benefit of discovery, shareholders will frequently come up against difficulties in pleading for permission to continue derivative litigation. While the judiciary maintain that the procedural standards are the lowest possible burden, which can be met with 'a credible showing, through documents, logic, testimony or otherwise, that there are legitimate issues of wrongdoing, ${ }^{112}$ it ignores the subtle obstacles, such as institutional inertia ${ }^{113}$ or shareholder passivity, ${ }^{114}$ that inhere the corporate structure when it comes to enforcing corporate wrongdoing. All the board needs to do is delegate the litigation decision to a committee that is formally independent. Provided the committee adequately considers the litigation and discloses its reasons, that committee's decision is then not reviewed in light of the court's own business judgment, meaning the courts will not look to overcome subtler problems that face shareholders in derivative litigation, such as lack of expertise, information asymmetry, or structural bias. ${ }^{115}$

American scholars have highlighted that the US system contains several procedural checks and balances that restrict frivolous litigation. ${ }^{116}$ Coffee and Schwartz also consider that if procedural demands place an unrealistic demand on shareholders occasions will arise where meritorious claims will not be pursued 'because of either lack of access to the relevant facts or financial naïveté' and the deterrent function will not survive. ${ }^{117}$ Despite the existing

\footnotetext{
${ }^{109}$ For example, independence is only denied in those situations where there is a clear factual link between the committee and the company, Re Oracle Corporation. Derivative Litigation, 824 A.2d 917, 942-3 (Del. Ch. 2003); and Beam v Martha Stewart, 845 A.2d 1040, 1050 (2004) - independence is not impugned solely on the basis of friendships or outside business relationships.

110 Gaines v Haughton, 645 F.2d 761 (9th Cir. 1981).

111 See, for example, Re Par Pharmaceutical, Inc. Derivative Litigation, 750 F. Supp. 641 (S.D.N.Y. 1990) (decision reached by committee on "secret documents" was not a satisfactory explanation); Re Southern Peru Copper Corporation Shareholder Derivative Litigation 52 A.3d 761 (Del. Ch. 2011) (committee should assess whether self-dealing was fair, assessment was more than a check-box exercise); Holmstrom v. Coastal Indus., Inc., 645 F. Supp. 963, 972 (N.D.Ohio 1984) (report devoid of factual findings); Watts v. Des Moines Register \& Tribune, 525 F. Supp. 1311, 1328-29 (S.D.Iowa 1981) (postponing decision pending discovery of factors influencing committee's decision which were not presented in report); see also Aronson v Lewis, 473 A.2d 805, 814-5 (Del. 1984).

112 Seinfeld v Verizon Communications Inc, 909 A.2d 117, 124 (2006).

113 J Hoppmann et al., Boards as a Source of Inertia: Examining the Internal Challenges and Dynamics of Boards of Directors in Times of Environmental Discontinuities, Academy of Management Review (forthcoming 2018); S Kaplan and R Henderson, Inertia and Incentives: Bridging Organizational Economics and Organizational Theory 16(5) Organization Science 509 (2005).

${ }^{114}$ A Reisberg (n 2) at 3.4.1.1-3; J Coffee and D Schwartz (n 8) at 280-4, 301.

${ }^{115}$ A Reisberg (n 2) at 3.4.1.2; J Coffee and D Schwartz (n 8) at 301, 328.

${ }^{116}$ See, for example, B Lebovitch and J Kwawegen, Of Babies And Bathwater: Deterring Frivolous Stockholder Suits Without Closing the Courthouse Doors to Legitimate Claims 40 Delaware Journal of Corporate Law 491 (2016), passim; R Thompson and R Thomas (n 2) at 1773-4.

117 J Coffee and D Schwartz (n 8) at 287, 315; see also A Reisberg (n 2) at 3.4.1.3.
} 
mechanisms that are designed to deter frivolous litigation, this analysis of factual implementation reveals that the courts are reluctant to grant access to information or form its own business judgment. This can make it difficult for shareholders to discharge the relevant burdens of their claim regardless of merit. These obstacles would appear to make litigation a futile exercise, but the US continues to observe comparatively higher levels of derivative enforcement. The answer, we assert, lies not in how costs are allocated but how costs will be allocated in light of de facto implementation by the court.

While it may be the case that a shareholder will look to the "path of least resistance", the question of where that path is meant to be leading to remains open. A shareholder may be displeased with company fortunes and suspect wrongdoing but in a liquid market it is far easier for them to exit. ${ }^{118}$ Any such compensatory role of derivative litigation for the shareholder is often described as trivial. ${ }^{119}$ In such circumstances, why litigate? It is the incentives of the attorney that influence the shareholder's behaviour. ${ }^{120}$ The attorney is looking to recover their fee. Attorney's may piggyback off monitoring efforts of others, such as mandatory or voluntary public disclosures, to discover potentially litigious conduct. Finding a shareholder to bring the claim is subsequently a fairly easy task. ${ }^{121}$

The way the courts then approach derivative litigation explains why it is a worthwhile pursuit for the attorney to "pressure" the shareholder into litigation. For the attorney to recover their fee they only need to achieve a "substantial benefit" for the company, which need not be monetary. Directors, on the other hand, are risk averse, as their value is tied up in a single company. ${ }^{122}$ Defending litigation is likely to harm their value in the managerial labour market. While the company may refuse demand, shareholders often look to have demand excused. ${ }^{123}$ Directors cannot then simply refuse demand with a pithy and cursory refusal. They will need to counter claims that seek to create reasonable doubt about the independence and good faith of the board or that it was a decision protected by the business judgment rule, or they may defer the decision to a special litigation committee. ${ }^{124}$

However, the time and cost of doing so may well pale in comparison to simply settling the dispute. ${ }^{125}$ This is because the courts require the reasons for the transaction or the decision of the special litigation committee to be explained on the evidence at the preliminary hearing. Inadequate explanations will not be accepted, so the committee must review the situation properly even though they know the conclusion will almost invariably be dismissal and the

118 D Donald, Shareholder Voice and Its Opponents 5(2) Journal of Corporate Law Studies 305, 306 (2005).

${ }_{119}$ See, for example, A Reisberg (n 2) at 2.3; S Bhagat and R Romano, Event Studies and the Law: Empirical Studies of Corporate Law 4 American Law \& Economics Review 380, 407 (2002); R Romano, The Shareholder Suit: Litigation Without Foundation? 7 Journal of Law, Economics, and Organization 55, 62 (1991); J Cox, Compensation, Deterrence, and the Market as Boundaries for Derivative Suit Procedures 52 George Washington Law Review 745, 762 (1983); D Fischel and M Bradley (n 3) at 292; J Coffee and D Schwartz (n 8) at 302-7; cf. S Ferris et al. (n 11); R Thompson and R Thomas (n 2) at 1777.

${ }^{120}$ R Romano, The Shareholder Suit (n 119); J Coffee and D Schwartz (n 8); see also P Lazarsfeld et al., The People's Choice: How the Voter Makes Up His Mind in a Presidential Campaign (Duell Sloan and Pearce, 1944) for how individuals may have competing influences in which path to take.

$121 \mathrm{~J}$ Coffee, Understanding the Plaintiff's Attorney: The Implications of Economic Theory for Private Enforcement of Law Through Class and Derivative Actions 86(4) Columbia Law Review 669, 683(1986).

${ }^{122}$ D Fischel and M Bradley (n 3) at 265-6.

${ }^{123}$ Rales v Blasband, Del.Supr., 634 A.2d 927, 933 (1993); R Thompson and R Thomas (n 2) at 1774, 1782.

${ }^{124}$ See, for example, Re Walt Disney Co. Derivative Litigation, 825 A.2d 275 (Del. Ch. 2003).

${ }^{125}$ See discussion in H Butler and L Ribstein, Opting out of Fiduciary Duties: A response to the AntiContractarians 65 Washington Law Review 1, 55 (1990). 
courts will not second-guess it. Rather than incurring those costs, it is cheaper to settle that matter through monetary relief or some sort of token gesture, such as appointing an independent director. ${ }^{126}$ Hence, while it is tempting to view derivative lawsuits as non-frivolous and reducing agency costs by pointing to improvements in internal corporate governance or some monetary relief, ${ }^{127}$ a contrary explanation is that these results are evidence of rational bargaining regardless of the claim's merit or over optimistic claimants or defendants hoping for litigation victory despite the odds. Such behaviour may well drive up agency costs if a settlement or other cheaper mechanism was available to settle the matter. ${ }^{128}$

In short, the courts factual implementation dictates that boards must take derivative litigation seriously. They will not accept spurious reasoning from the board or committees creating the prospect of expensive litigation if the matter is not settled.

\section{b. UK Perspective II}

Despite the formal convergence of the systems and, in some respects, the UK system going further than the US regarding formal enactment of its derivative procedure, the UK is yet to see a surge in derivative enforcement. Empirical evidence reveals what has been referred to as the 'sine quibus non' for the courts to grant permission de facto in derivative claims. ${ }^{129}$ That is, courts are reluctant to depart from the ingrained tradition that enforcement of corporate rights is generally a matter for the board, except when there is a claim with: 1) sufficient legal merit; and 2) the claimant is the proper person. All claims have failed where either of these conditions are absent. This follows the pattern of the equitable procedure. Once factual implementation is taken into account, much like the US system, how costs will be allocated can help predict outcomes.

Shareholders will continue to find it difficult to satisfy these conditions of the court as they did under the equitable procedure. Enforcement levels are unlikely to rise if courts are unwilling to apply its discretion to overcome the incentive bias and defer to the business judgment of the board. This is because the consequence of factual implementation will normally leave the shareholder liable for the costs. Put another way, they are not pressured by conflicting influences like the US shareholder. Both shareholders and solicitors are unlikely to view litigation as profitable. Simultaneously little to no additional risk is shifted to directors. They must merely cast doubt over the merits of the claim or establish a principle as to why the shareholder should not continue. Indeed, derivative litigation may be even less costly to directors under the statutory procedure due to the reduction in time that is spent in court on this preliminary matter. ${ }^{130}$ Therefore, any cost and time associated to defending the claim may well be minimal and recoverable from the other side.

\footnotetext{
${ }^{126} \mathrm{~S}$ Ferris et al. (n 11) at 154.

${ }^{127} \mathrm{~S}$ Ferris et al. (n 11) at 157-63; the same could be said of R Thompson and R Thomas (n 2) at 1749, 1773-4, 1776 - who offer contradictory remarks about lawyers only choosing to file a case when they are certain they can satisfy the requirements but elsewhere using data that shows $60-70 \%$ of claims are dismissed quickly.

${ }^{128}$ See, J Coffee (n 121) at 700.

${ }^{129}$ D Gibbs-Kneller and C Ogbonnaya (n 2); D Gibbs and C Ogbonnaya, Derivative Claims Quantitative Analysis 1874-2017 [Data Collection] (Colchester, Essex: UK Data Archive, 2018) DOI 10.5255/UKDA-SN-853366 .

${ }^{130} \mathrm{Ibid}$ - the data reveals a significant decrease in time spent in court $(\mathrm{p}<0.05)$ under the statutory procedure when compared with the equitable procedure.
} 
Consider how the factual implementation continues to bias incentives in favour of directors despite the statutory procedure appearing more accessible. The first condition is that, contrary to proclamations from the court, such as the one from Stainer $v$ Lee that claims with weak merit may still be successful where the court forms an "overall view" that permission should continue, ${ }^{131}$ the claim must have sufficient merit to continue. For example, one claim required there to be an "obvious breach of duty" 132 while another was successful where the merits were described as "so powerful" and "sufficiently substantiated". ${ }^{133}$

The problem for shareholders is evident when rules relating to information disclosure are considered. The shareholder is not normally able to obtain disclosure prior to the claim that would reveal the possibility of a claim revealing an obvious breach. The shareholder must undertake the risk of pursuing a claim to benefit from the disclosure rules. If the company produces the information, it is no guarantee enough evidence will be produced that discloses the sufficient merit required for permission to be given. Failure to do so will leave the shareholder liable for the costs. The shareholder also has to contend with institutional inertia. The board is likely to resist such claims. ${ }^{134}$ For example, in one claim a shareholder could not rationalise or co-ordinate their assertions of market manipulation, which the board easily dispensed with by asserting that a number of factors can contribute to the share value of a company. ${ }^{135}$ Evidently the court took a very dim view of the shareholder's claim but made no attempt to assist them in substantiating their claim by requiring the board to explain in more detail.

Short of passivity or spurious tactics by the directors, that the courts do not look on kindly, institutional inertia can make this condition difficult to satisfy. Even then it may produce no more than a Pyrrhic victory for the shareholder who may only achieve permission down to disclosure or have their indemnity capped. Therefore, the unwillingness of the court to apply its discretion and instead impose a condition of 'sufficient merit' will incentivise the directors to deter litigation, as they will be rationally 'inclined to exploit informational and positional advantages vis-à-vis shareholders'. ${ }^{136}$ Shareholders will have little incentive to pursue litigation if the court merely requires some rudimentary evidence to cast doubt over the legitimacy of the claim and refuse permission.

Suppose a shareholder can disclose sufficient merit to their claim. The adherence to the proper person test and its principles will deter most claimants. 'Permission ... is a discretion resting in the court' and 'the discretion must, of course, be exercised in accordance with established principles'. ${ }^{137}$ Perhaps the principal one to consider for larger companies and to draw a

\footnotetext{
${ }^{131}$ Stainer $v$ Lee [2010] EWHC 1539 (Ch) at [29]; see also, Hughes v Weiss [2012] EWHC 2363 (Ch) at [33].

${ }^{132}$ Franbar Holdings Ltd v Patel [2008] EWHC 1534 (Ch); [2008] BCC 885 at [37].

${ }^{133}$ SRI Retail Services Ltd v King [2017] EWHC 737 (Ch) (CHD) at [68]-[75].

${ }^{134}$ For examples of this in UK case law see, SRI Retail Services Ltd v King [2017] EWHC 737 (Ch) (CHD) at [29]-[33]; Kiani v Cooper [2010] EWHC 577 (Ch); [2010] BCC 463 at [30]; Stainer v Lee [2010] EWHC 1539 (Ch); [2011] BCC 134 at [10]-[11], [13]; Franbar Holdings Ltd v Patel [2008] EWHC 1534 (Ch); [2008] BCC 885 at [15], [22]; Airey v Cordell [2006] EWHC 2728 at [15]-[16]; Wallersteiner v Moir (No 2) [1975] QB 373, $389,396$.

${ }^{135}$ Bridge v Daley [2015] EWHC 2121 (Ch) at [40]-[46].

${ }^{136}$ M Moore, Private Ordering and Public Policy: The Paradoxical Foundations of Corporate Contractarianism, Oxford Journal of Legal Studies 1, 19 (2014) citing L Bebchuk, The Debate on Contractual Freedom in Corporate Law 89 Columbia Law Review 1395 (1989); see also, M Eisenberg, The Structure of Corporation Law 89 Columbia Law Review 1461 (1989).

${ }^{137}$ Cinematic Finance Ltd v Ryder [2010] EWHC 3387 (Ch) at [14], [21]; [2012] BCC 797.
} 
comparison with the US is independent views, either from shareholders or directors. ${ }^{138}$ Where such views are solicited the courts will invariably defer to that judgment short of illegitimacy. ${ }^{139}$ Much like the US system, formal independence is used to deny possible conflicts, leaving subtler influences on independent directors to fall between the cracks. In Kleanthous $v$ Paphitis, for example, a committee set up to assess the value of the claim was considered formally independent as the members had received advice on their legal duties despite being associates of the defendant director. ${ }^{140}$

As well as only requiring formal independence the courts seem to be satisfied that a claim should be dismissed if the independent views conclude that it should. The court does not appear to investigate how those conclusions were reached, unless they were obtained illegitimately. ${ }^{141}$ For example, in Kleanthous the court accepted the conclusions of the committee that:

After careful consideration the directors concluded that:

(a) the negative effect on the Company's businesses of the Company bringing or continuing a claim against the Defendant Directors greatly outweighs any benefit to the Company by pursuing the claim; and

(b) bringing or continuing the claim against the Defendant Directors would not promote the success of the Company.

They then refused the argument of the claimant that seriously egregious conduct should defeat the committee's view. ${ }^{142}$ Contrary to the US position, which requires the rationale for the committee's decision to be spelled out clearly to the court, the principle of independent views resembles that of demand-refused cases in the US. That is, all the court appears to require is the committee's assertion to be put in conclusory terms and this throws the burden onto the shareholder to show it was illegitimate. That is a difficult burden to discharge, as Reisberg recognises, because they are likely to lack the finances and information to appropriately challenge the decision. ${ }^{143}$ The same outcome applies if it is independent shareholders solicited. They are unlikely to support the claim and it will be very difficult to challenge that decision. For example, in Bridge $v$ Daley practically no independent shareholders supported the claim and the court did not investigate why those views were reached. ${ }^{144}$ Simultaneously, by the courts respecting independent views, it throws no additional burden on the directors to substantiate their defence, which would otherwise increase the cost and potential risk to them.

\footnotetext{
${ }^{138}$ For the equitable procedure on independent views, see, for example, Airey v Cordell [2006] EWHC 2728 (Ch); [2007] BCC 785 at [53]; Smith v Croft (No 2) [1988] Ch 114; Smith v Croft (No 1) [1986] 1 W.L.R. 580, 590; Wallersteiner v Moir (No 2) [1975] QB 373, 404; and for examples under the statutory procedure see, Bridge v Daley [2015] EWHC 2121 at [56]; Kleanthous $v$ Paphitis [2011] EWHC 2287 (Ch); (2011) 108(36) LSG 19 at [75], [83]; Stainer v Lee [2010] EWHC 1539 (Ch); [2011] BCC 134 at [46].

${ }^{139}$ Stainer v Lee [2010] EWHC 1539 (Ch); [2011] BCC 134 at [46].

${ }^{140}$ Kleanthous v Paphitis [2011] EWHC 2287 (Ch); (2011) 108(36) LSG 19 at [75]; supra (n 109) - showing formal independence judged similar to the US position

${ }^{141}$ Stainer v Lee [2010] EWHC 1539 (Ch); [2011] BCC 134 at [46].

${ }^{142}$ Kleanthous v Paphitis [2011] EWHC 2287 (Ch); (2011) 108(36) LSG 19 at [31], [75].

${ }^{143}$ A Reisberg (n 2) at ch 3.4.1.2.

${ }^{144}$ Bridge v Daley [2015] EWHC 2121 (Ch) at [55]-[57], [68]; cf. Stainer v Lee [2010] EWHC 1539 (Ch); [2011] BCC 134 at [46].
} 
An added problem with this principal is that independent views may be solicited at any time in proceedings. A shareholder might undergo the time and expense of trying to establish sufficient merit only for it to be dismissed on the basis of independent views. ${ }^{145}$

Despite reforms to civil litigation funding, the sine quibus non limits any practical utility of indemnities, conditional fee arrangements and third party funders in the context of derivative litigation that may otherwise incentivise shareholders to litigate by reducing the personal risk to them. The high threshold of establishing sufficient legal merit and the adherence to established legal principles that are all geared towards refusal make permission unlikely to be given. Solicitors and third parties are then no more likely than shareholders to take the risk or front the cost of enforcement and cross-pressure shareholders into litigation when they are highly unlikely to see any return because the costs of unsuccessful claims will still be borne by the claimant. Likewise, directors do not appear to incur any additional risk or time associated with derivative claims under the statute. Thus, there is no increased cost in derivative litigation that may otherwise incentivise them to settle the claim like in the US.

\section{Concluding Remarks: Lessons Learnt from Comparison}

The observations from this article have demonstrated that the way the courts factually implement derivative procedures can contribute to the level of enforcement in a legal system. They should not be taken further to assert what the optimum level of shareholder derivative enforcement is. What, exactly, a shareholder-centric model should look like remains unresolved. For example, some in the UK and US maintain that for the deterrent function to survive the court must maintain some level of discretion to overcome the incentive bias in the corporate structure that favours directors in derivative litigation. ${ }^{146}$ However, others contend that the court should not interfere and freedom of contract should prevail. ${ }^{147}$ Fundamentally, the debate involves a comparative institutional analysis: When it comes to reducing agency costs, are courts able to improve outcomes relative to private ordering?

It is not for this article to say that the court should be liberal or parsimonious in the discretion that is afforded to them. What we can say is that the courts are reluctant to impart their own business judgment on conduct and litigation decisions of the board in both systems. This can have consequences for enforcement levels because of the way costs will be allocated between the parties under English or American rule. Both systems have a liquid market and the compensatory function of derivative litigation may be minimal. This may mean that shareholder exit appears to be the "path of least resistance", but the willingness of courts in the US to review the substance of board and committee decisions creates conflicting influences for shareholders that are not present in the UK system.

In the US, the shareholder faces influence from the attorney to litigate instead of exit because, absent fee-shifting being imposed, it is often in all parties' interests to settle the claim. Thus, claims are brought and settled to avoid higher litigation costs that are involved with having a court review the board's or committee's decision. Other studies suggest such claims are not

145 Companies Act 2006, ss 261-4.

${ }^{146}$ A Reisberg (n 2) at 5.4.2; J Coffee and D Schwartz (n 8) at 287.

${ }^{147}$ D Fischel and M Bradley (n 3) at 286-92; H Butler and L Ribstein (n 125) at 55-63. 
"strike-suits" or frivolous, as they achieve some relief, and perceived as reducing agency costs. However, a contrary explanation may well be that these results are often a product of rational bargaining between the parties. That some claims are continued to their full conclusion might be viewed as the product of over optimistic shareholders and attorneys or directors. Both of these situations could contribute to higher agency costs than are necessary.

Thus, we may conclude that factual implementation in the US contributes to higher levels of derivative enforcement. The outcome for agency costs though may be positive in several senses. It may produce some monetary relief or cosmetic corporate governance improvements. Directors must also give full and proper attention to their decisions that they make. Conversely, it may encourage litigation regardless of merit. This can take valuable resources away from the company but also encourage a highly mechanistic view of derivative litigation. The board and any special litigation committee know that courts factually implementing the demand requirement or reviewing a special litigation committee decision will generally see them as formally independent and refer to their business judgment, provided they haven't simply fudged the findings. Such decisions may not be made truly in light of whether litigation will serve the corporate purpose but as a result of institutional inertia and a desire to rally around one's own peers.

The UK system does not create such conflicting influences on the shareholder. Short of a seriously egregious and obvious breach of duty, the risk of costs liability to the shareholder is high regardless of who is funding the litigation. A director who is alert to the incentive bias will rationally exploit their informational and positional advantages to deter litigation. Despite the transition to the statutory procedure, the factual implementation is likely to lead to similar results. The director need only cast some doubt over the claim's merit and, failing that, establish a principle why the shareholder should not continue the claim. By doing so, they will shift the costs of derivative litigation on to the claimant. The possible consequences for agency costs are then positive in respect to any frivolous litigation. However, in the absence of any derivative enforcement, where other mechanisms fail to control opportunistic behaviour directors may act with impunity contrary to the corporate purpose. 